Edunomika - Vol. 02, No. 01 (Pebruari 2018)

\title{
UPAYA MENINGKATKAN HASIL BELAJAR MENGGUNAKAN PERANGKAT LUNAK PENGOLAH KATA WORD 2007 UNTUK MENYAJIKAN INFORMASI MELALUI METODE SIMULASI PADA SISWA KELAS VIII B SEMESTER 1 SMP NEGERI 7 SUKOHARJO TAHUN 2017/2018
}

\author{
Endar Setyawan \\ SMP Negeri 7 Sukoharjo, Jawa Tengah \\ Email: endarsetyawan@gmail.com
}

\begin{abstract}
Abstrak: Penelitian ini bertujuan untuk meningkatkan hasil belajar TIK materi menggunakan perangkat lunak pengolah kata word 2007 melalui metode simulasi pada siswa kelas VIII B SMP Negeri 7 Sukoharjo Semester I Tahun Pelajaran 2017/2018. Metode penelitian menggunakan Penelitian Tindakan Kelas yang dilaksanakan dalam dua siklus setiap siklus terdiri dua kali pertemuan, dengan empat tahap penelitian: perencanaan, pelaksanaan, pengamatan dan refleksi. Subjek penelitian ini adalah siswa-siswi kelas VIII B SMP Negeri 7 Sukoharjo tahun ajaran 2017/2018. Dengan jumlah 31 siswa. Teknik pengumpulan data yang digunakan adalah observasi, wawancara, tes, dan dokumentasi. Analisis data yang digunakan dalam penelitian ini adalah analisis deskriptif kualitatif. Hasil penelitian ini adalah meningkatkan hasil belajar TIK materi menggunakan perangkat lunak pengolah kata word 2007. Hal ini dibuktikan dengan peningkatan hasil belajar siswa pada siklus I siswa yang berhasil mendapat nilai KKM, meningkat dari 18 siswa $(58,06 \%)$ menjadi 21 siswa atau 67,74\% atau terdapat peningkatan sebesar 9,68\%. Sedangkan pada siklus II meningkat menjadi 27 siswa yang mendapat nilai diatas KKM atau 87,09\% atau terdapat peningkatan sebesar 19,35\% dari sebelumnya. Berdasarkan hasil penelitian ini dapat disimpulkan bahwa dengan penerapan metode simulasi dapat meningkatkan hasil belajar mendiskripsikan pelaku ekonomi masyarakat pada siswa kelas VIII B SMP Negeri 7 Sukoharjo Semester I Tahun Pelajaran 2017/2018.
\end{abstract}

Kata kunci: hasil belajar, perangkat lunak pengolah kata word 2007, metode simulasi

Abstract: This study aims to improve the learning outcomes of ICT materials using word processing software 2007 through simulation methods on students of class VIII B SMP Negeri 7 Sukoharjo Semester I Lesson 2017/2018. The research method using Classroom Action Research which is carried out in two cycles each cycle consists of two meetings, with four stages of research: planning, implementation, observation and reflection. The subject of this research is the students of class VIII B SMP Negeri 7 Sukoharjo academic year 2017/2018. With 31 students. Data collection techniques used are observation, interviews, tests, and documentation. Data analysis used in this research is descriptive qualitative analysis. The result of this research is to improve the learning result of ICT material using word processing software word 2007. This is proved by the improvement of student learning outcomes in the first cycle of students who successfully got KKM score, increased from 18 students $(58.06 \%)$ to 21 students or $67,74 \%$ or an increase of $9.68 \%$. While in the second cycle increased to 27 students who got a value above the KKM or $87.09 \%$ or an increase of $19.35 \%$ from the previous. Based on the results of this study can be concluded that with the implementation of simulation method can improve learning outcomes to describe economic economic actors in students of class VIII B SMP Negeri 7 Sukoharjo Semester I Lesson $2017 / 2018$.

Keywords: learning result, word processing software word 2007, simulation method 


\section{PENDAHULUAN}

Teknologi Informasi dan Komunikasi (TIK) sebagai bagian dari ilmu pengetahuan dan teknologi (IPTEK) secara umum adalah semua yang teknologi berhubungan dengan pengambilan, pengumpulan (akuisisi), pengolahan, penyimpanan, penyebaran, dan penyajian informasi(Kementerian Negara Riset dan Teknologi, 2006: 6). Teknologi informasi juga adalah suatu teknologi yang digunakan untuk mengolah data termasuk memproses, mendapatkan, menyusun, menyimpan, memanipulasi data dalam berbagai cara untuk menghasilkan informasi yang berkualitas, yaitu informasi yang relevan, akurat, dan tepat waktu yang digunakan untuk keperluan pribadi, bisnis, dan pemerintahan dan merupakan informasi yang strategis untuk pengambilan keputusan.

Mata pelajaran TIK (Teknologi Informasi dan Komunikasi) mulai diperkenalkan sejak adanya kurikulum berbasis kompetensi (KBK) tahun 2004 atau biasa disebut dengan KTSP, sekitar 2 tahun berikutnya, yaitu 2006, TIK menjadi mata pelajaran tersendiri pada jenjang pendidikan SD, SMP, dan SMA. Dengan diterapkannya mata pelajaran TIK sebagai mata pelajaran di sekolah ada beberapa manfaat yang didapat oleh siswa antara lain; siswa mendapatkan pengetahuan dasar tentang pengoperasian komputer, siswa tidak lagi mengerjakan tugas menggunakan mesin ketik, siswa semakin terampil mengoperasikan software untuk menunjang pelajaran mereka, misalnya persiapan materi presentasi, mencari informasi /data pendukung ilmu pengetahuan melalui internet ataupun bertukar informasi secara cepat dan saling berkomunikasi. Pengetahuan TIK ini sangat penting sebagai dasar pengembangan siswa dalam memperdalam pengetahuan TIK di jenjang pendidikan berikutnya ataupun memacu kreativitas siswa. Hal ini sudah terbukti nyata semenjak ada pelajaran TIK. Banyak siswa yang menjadi terampil dan mandiri di bidang TIK setelah mereka belajar TIK. Mereka tidak lagi hanya mencari informasi tapi juga menciptakan informasi baru di internet. Oleh karena itu, pembelajaran yang berkaitan dengan TIK yang disampaikan kepada siswa SMP sederajat harus dapat disampaikan dengan metode pembelajaran yang baik dan benar sesuai dengan situasi kelas agar siswa dapat memahami dan mengetahui dalam penggunaan perangkat lunak pengolah kata word 2007.

Selama ini pembelajaran biasanya hanya disampaikan secara konvensional, dimana guru yang berperan aktif, sementara siswa cenderung pasif. Sikap siswa yang pasif dapat mengurangi keterlibatannya dalam mengikuti proses pembelajaran yang dapat mengakibatkan turunnya minat siswa dalam mengikuti proses pembelajaran. Dalam hal lain yang dapat dikatakan masalah adalah kurangnya rasa percaya diri dalam diri siswa untuk mengemukakan pendapat dan berbicara di depan umum. Banyak siswa yang lebih memilih untuk memendam pendapatnya selama proses pembelajaran. Sebagai pengajar, guru harus membantu siswa menggali kepercayaan diri mereka. Karena dengan adanya rasa percaya diri, siswa akan lebih yakin untuk berbicara di hadapan orang. Hasil belajar siswa sangat dipengaruhi oleh kualitas pembelajaran yang dilaksanakan di sekolah. Salah satu yang menentukan kualitas pembelajaran adalah penggunaan model pembelajaran yang tepat dengan materi yang diajarkan. Pengajaran pendidikan jika sesuai akan menghasilkan output yang cerdas IQ maupun SQ, karena pendidikan merupakan cara terbaik untuk meningkatkan kualitas sumber daya manusia suatu bangsa (Tho'in, 2017: 162). Pada kenyataannya banyak 
sekolah yang kurang memperlihatkan penggunaan model pembelajaran dalam setiap penampilan mengajar. Dari uraian panjang di atas terdapat beberapa hal yang dapat diambil sebagai kesimpulan penting, diantaranya adalah:

1. TIK dalam dunia pendidikan sangat diperlukan untuk memperlancar proses pembelajaran di kelas.

2. Dengan diterapkannya TIK di dunia pendidikan khususnya di tingkat Sekolah Dasar dapat melatih siswa menjadi lebih aktif dan kreatif serta mandiri.

3. TIK tidak hanya dapat dikuasai seorang guru yang mengajar bidang studi TIK saja, tetapi semua guru dapat memanfaatkannya meskipun tetap dengan pengawasan guru TIK sebagai penanggungjawab.

4. Dengan memanfaatkan TIK dalam pembelajaran di kelas memunculkan efek positif seperti kegiatan belajar mengajar dapat berjalan dengan efektif dan efisien sehingga beban kinerja guru di dalam kelas dapat terkurangi.

5. Dengan adanya TIK, siswa dapat mencari hal atau sesuatu yang baru yang tidak ada di dalam buku pegangan.

Upaya peningkatan prestasi belajar siswa tidak terlepas dari berbagai faktor yang mempengaruhinya. Dalam hal ini, diperlukan guru kreatif yang dapat membuat pembelajaran menjadi lebih menarik dan disukai oleh peserta didik. Suasana kelas perlu direncanakan dan dibangun sedemikian rupa dengan menggunakan model pembelajaran yang tepat agar siswa dapat memperoleh kesempatan untuk berinteraksi satu sama lain sehingga pada gilirannya dapat diperoleh prestasi belajar yang optimal. Untuk itu perlu disadari oleh guru bahwa dalam melaksanakan pembelajaran perlu pula diupayakan pembelajaran yang bersifat membangun dan memberikan pengalaman terhadap materimateri yang diberikan.

Keterbatasan waktu yang tersedia menyebabkan guru mengejar target pencapaian kurikulum memilih jalan yang termudah untuk menginformasikan fakta dan konsep, yaitu melalui model ceramah kemudian latihan soal dan siswa memperhatikan penjelasan guru tanpa melakukan aktivitas sehingga siswa pasif. Guru dalam mengajarkan TIK khususnya sub pokok bahasan menggunakan perangkat lunak pengolah kata word 2007 kepada siswa kurang melibatkan siswa secara aktif dalam interaksi belajar mengajar sehingga siswa kurang termotivasi dalam belajar. Guru juga kurang melibatkan lingkungan sebagai media sehingga siswa kurang mengenal lingkungan dan tidak dapat memperoleh pemahaman yang berarti. Disaat proses belajar mengajar berlangsung, guru kurang menggunakan model pembelajaran yang bervariasi sehingga hal tersebut dapat menyebabkan siswa jenuh dan kurang aktif.

Penggunaan berbagai macam model pembelajaran dapat memakan waktu yang lebih lama sementara waktu mengajarnya terbatas. Guru juga jarang sekali menggunakan pendekatan pembelajaran ketika sedang mengajarkan materi TIK. Terkait belum optimalnya proses pembelajaran TIK di kelas VIII B SMP Negeri 7 Sukoharjo, maka peneliti berupaya untuk menerapkan metode simulasi sebagai salah satu alternatif pembelajaran bermakna yang bermuara pada pembelajaran yang aktif, kreatif, efektif dan menyenangkan.

Menurut Pusat Bahasa Depdiknas (2005) simulasi adalah satu metode pelatihan yang memperagakan sesuatu dalam bentuk tiruan (imakan) yang mirip dengan keadaan yang 
sesungguhnya; simulasi: penggambaran suatu sistem atau proses dengan peragaan memakai model statistic atau pemeran. Udin Syaefudin Sa'ud (2005: 129) simulasi adalah sebuah replikasi atau visualisasi dari perilaku sebuah sistem, misalnya sebuah perencanaan pendidikan, yang berjalan pada kurun waktu yang tertentu. Jadi dapat dikatakan bahwa simulasi itu adalah sebuah model yang berisi seperangkat variabel yang menampilkan ciri utama dari sistem kehidupan yang sebenarnya. Simulasi memungkinkan keputusankeputusan yang menentukan bagaimana ciri-ciri utama itu bisa dimodifikasi secara nyata.

Sri Anitah, W. DKK (2007: 5.22) metode simulasi merupakan salah satu metode pembelajaran yang dapat digunakan dalam pembelajaran kelompok. Proses pembelajaran yang menggunakan metode simulasi cenderung objeknya bukan benda atau kegiatan yang sebenarnya, melainkan kegiatan mengajar yang bersifat pura-pura. Dalam pembelajaran yang menggunakan metode simulasi, siswa dibina kemampuannya berkaitan dengan keterampilan berinteraksi dan berkomunikasi dalam kelompok. Di samping itu, dalam metode simulasi siswa diajak untuk dapat bermain peran beberapa perilaku yang dianggap sesuai dengan tujuan pembelajaran.

\section{KAJIAN TEORI}

\section{Teori Hasil Belajar Siswa}

Menurut R. Gagne seperti yang dikutip oleh Slameto (2000:78) memberikan dua definisi belajar, yaitu belajar adalah suatu proses untuk memperoleh motivasi dalam pengetahuan, keterampilan, kebiasaan, dan tingkah laku. Belajar adalah penguasaan pengetahuan atau keterampilan yang diperoleh dari instruksi. Menurut Skinner yang dikutip oleh Dimyati dan Mudjiono (2006:93) bahwa belajar merupakan hubungan antara stimulus dan respon yang tercipta melalui proses tingkah laku. M. Sobry Sutikno (2010:35) mengemukakan belajar merupakan suatu proses usaha yang dilakukan oleh seseorang untuk memperoleh suatu perubahan yang baru sebagai hasil pengalamannya sendiri dalam interaksi dengan lingkungannya.

Berdasarkan beberapa pengertian di atas maka dapat penulis simpulkan bahwa belajar adalah perubahan serta peningkatan kualitas dan kuantitas tingkah laku seseorang di berbagai bidang yang terjadi akibat interaksi terus menerus dengan lingkungannya.

Hasil belajar siswa menurut W. Winkel (2004:82) adalah keberhasilan yang dicapai oleh siswa, yakni prestasi belajar siswa di sekolah yang mewujudkan dalam bentuk angka. Hasil belajar adalah pola-pola perbuatan, nilai-nilai, pengertian-pengertian, sikap-sikap, apresiasi dan keterampilan-keterampilan (Suprijono, 2011:5). Hasil belajar adalah hasil yang dicapai dalam bentuk angka atau skor setelah tes hasil belajar pada setiap akhir pembelajaran (Dimyati dan Mujiono, 2006:24).

Definisi di atas dapat disimpulkan bahwa hasil belajar adalah prestasi belajar yang dicapai siswa dalam proses kegiatan belajar mengajar dengan membawa suatu perubahan dan pembentukan tingkah laku seseorang. Untuk menyatakan bahwa suatu proses belajar dapat dikatakan berhasil, setiap guru memiliki pandangan masing-masing sejalan dengan filsafatnya. Namun untuk menyamakan persepsi sebaiknya kita berpedoman pada kurikulum yang berlaku saat ini yang telah disempurnakan, antara lain bahwa suatu proses belajar 
mengajar tentang suatu bahan pembelajaran dinyatakan berhasil apabila tujuan pembelajaran khususnya dapat dicapai.

Dalam rangka mengetahui tercapai tidaknya tujuan pembelajaran khusus, guru perlu mengadakan tes formatif pada setiap menyajikan suatu bahasan kepada siswa. Penilaian formatif ini untuk mengetahui sejauh mana siswa telah menguasai tujuan pembelajaran khusus yang ingin dicapai. Fungsi penelitian ini adalah untuk memberikan umpan balik pada guru dalam rangka memperbaiki proses belajar mengajar dan melaksanakan program remedial bagi siswa yang belum berhasil. Karena itulah, suatu proses belajar mengajar dinyatakan berhasil apabila hasilnya memenuhi tujuan pembelajaran khusus dari bahan tersebut.

Hasil belajar yang dicapai oleh siswa di sekolah merupakan salah satu ukuran terhadap penguasaan materi pelajaran yang disampaikan. Peran guru dalam menyampaikan materi pelajaran dapat mempengaruhi hasil belajar siswa. Faktor-faktor yang mempengaruhi hasil belajar siswa penting sekali untuk diketahui, artinya dalam rangka membantu siswa mencapai hasil belajar yang seoptimal mungkin. Hasil belajar akan semakin maksimal jika semua unsur masyarakat menyadari pentingnya pendidikan, karena pendidikan cara perbaik memperbarui kualitas bangsa (Tho'in, 2017).

Hasil belajar yang dicapai siswa dipengaruhi oleh dua faktor baik yang bersifat mendorong atau menghambat, demikian pula dalam belajar. Faktor yang mempengaruhi prestasi atau hasil belajar siswa yakni faktor dari dalam diri siswa (interen) dan faktor yang datang dari luar (eksteren). Ahmadi (1998:72) mengemukakan untuk mencapai prestasi belajar siswa sebagaimana yang diharapkan, maka perlu diperhatikan beberapa faktor yang mempengaruhinya antara lain faktor yang terdapat dalam diri siswa (faktor intern) dan faktor yang berasal dari luar diri siswa (faktor ekstern).

\section{Perangkat Lunak Pengolah Kata Word 2007}

Microsoft Word 2007 adalah salah satu aplikasi dari Microsoft Office 2007. Microsoft Word 2007 merupakan versi ke-12 dari pengembangan perangkat lunak pengolah kata Microsoft Word. Microsoft Word 2007 dirilis pada 11 Desember 2007 oleh perusahaan pengembang perangkat lunak Microsoft Corporation. Aplikasi Microsoft Word dijalankan dengan system operasi berbasis Windows. Selain fasilitas yang semakin lengkap, penambahan Menu Ribbon dan Office Button pada Microsoft Word 2007 menjadikan tampilan Microsoft Word 2007 berbeda dan belum pernah ada pada versi sebelumnya. Untuk memulai program Microsoft Word 2007 tidak berbeda dengan memulai program Microsoft Word sebelumnya, yaitu:

1. Klik tombol Start pada Taskbar

2. Pilih All Programs

3. Klik Microsoft Office

4. Klik Microsoft Office Word 2007

Cara lain untuk memulai program Microsoft Word 2007 adalah dengan double klik shortcut Microsoft Word 2007 yang berada di desktop. Shortcut adalah ikon yang terletak pada desktop yang mewakili suatu program. Bias juga dikatakan bahwa shortcut adalah jalan pintas untuk membuka sebuah program. Jika pada desktop belum terdapat shortcut untuk 
Microsoft Word 2007, maka kalian dapat membuat shortcut sendiri. Untuk membuat shortcut program pada desktop dengan cara:

1. Klik Start pada Taskbar

2. Klik All Programs

3. Klik Microsoft Office

4. Klik kanan Microsoft Office Word 2007

5. Pilih Send To

6. Klik Desktop

Maka pada desktop telah ditambah satu shortcut Microsoft Word 2007. Langkah di atas dapat pula digunakan untuk membuat shortcut program lain. Setelah program Microsoft Word 2007 dijalankan maka akan muncul jendela Microsoft Word 2007 dengan berbagai komponen untuk menjalankan fungsi-fungsi dalam pengolah kata. komponen-komponen yang terdapat pada jendela Microsoft Word 2007 adalah:

1. Title Bar. Title Bar (Baris Judul) berisi informasi nama dokumen yang sedang dijalankan pada program Microsoft Word 2007. Nama dokumen baru pada Microsoft Word adalah Document1.

2. Office Button. Office Button merupakan tombol untuk mengaktifkan berbagai macam menu perintah.

3. Quick Access Toolbar. Quick Access Toolbar berisi tombol-tombol menu yang digunakan untuk mempercepat perintah dalam pengerjaan dokumen. Tombol-tombol pada Quick Access Toolbar merupakan shortcut dari perintah yang ada di Office Button

4. Option Bar. Option bar adalah deretan ikon untuk mengatur tampilan jendela program. Ikon pada Option bar adalah:

a. Minimize: digunakan untuk menyembunyikan jendela program pada Taskbar.

b. Maximize/Restore: memaksimalkan ukuran tampilan jendela program/mengembalikan tampilan jendela pada ukuran semula.

c. Close: untuk menutup jendela program.

5. Tab Menu dan Ribbon (Ribbon Menu). Ribbon Menu merupakan tempat menu-menu perintah yang digunakan untuk mengedit dokumen. Ribbon Menu terdiri atas Menu Bar dan Toolbars. Menu bar (Baris Menu) berisi barisan perintah menu, yaitu Home, Insert, Page Layout, References, Mailings, Review, dan View. Sedangkan Toolbars berisi tombol perintah menu yang merupakan isi dari menu-menu perintah dalam Menu bar. tampilan Toolbar berubah-ubah tergantung pada menu yang diaktifkan. Toolbar ini dikelompokkan ke dalam Ribbon.

6. Document Area. Document Area terletak di tengah jendela berupa area putih seperti kertas kosong yang siap untuk ditulisi. Daerah ini merupakan daerah untuk mengetik dan mengedit dokumen.

7. Kursor. Kursor merupakan garis tegak berkedip. Semua karakter yang diketik akan muncul dari kursor ini.

8. Scroll Bar. Scroll Bar berfungsi untuk menggeser layar dokumen kerja. Jika menggeser layar dokumen kerja ke kiri atau ke kanan, gunakan Horizontal Scroll Bar sedangkan jika untuk menggeser layar dokumen kerja ke atas dan kebawah, gunakan Vertical Scroll Bar. 
9. Status Bar. Status Bar menampilkan informasi tentang posisi kursor, jumlah halaman, jumlah kata, serta informasi lain tentang dokumen yang sedang dikerjakan.

\section{Metode Simulasi}

Metode simulasi merupakan salah satu metode pembelajaran yang memberikan penyajian berupa pelajaran dengan menggunakan situasi maupun suatu proses yang nyata. Dalam metode jenis ini, siswa diminta untuk terlibat secara aktif dalam melalukan interaksi dengan situasi yang ada disekitar lingkungannya. Siswa diminta untuk menerapkan pengetahuan yang telah diperoleh atau yang telah dipelajari sebelumnya. Pengertian tersebut menunjukkan bahwa dalam metode simulasi penerapan antara teori dengan kehidupan nyata dalam bentuk praktek, sangat diperlukan oleh siswa. Sebenarnya apa sih tujuan dari metode pembelajaran dengan teknik simulasi ini? Sehingga siswa diminta untuk menerapkan teori yang telah di pelajari.

Setiap metode pembelajaran tentu saja memiliki tujuan-tujuan tertentu yang ingin dicapai, ketika telah diterapkan pada siswa. Lalu, apakah tujuan dari metode simulasi ini? Tujuan dari metode pembelajaran dengan teknik simulasi, yaitu:

a. Membantu siswa dalam menerapkan keterampilan untuk membuat keputusan dan dalam menyelesaikan masalah.

b. Membantu siswa untuk mengembangkan kemampuan dalam berinteraksi antarsesama manusia.

c. Guru memberikan kesempatan pada siswa untuk menerapkan tentang berbagai prinsip dan teori.

d. Membantu siswa untuk meningkatkan kemampuan kognitif, afektif, dan psikomotornya.

Sandra de Young dalam Nursalim dan Efendi (2008) menyatakan terdapat tiga jenis dari simulasi. Jenis-jenis dari simulasi dapat dijelaskan sebagai berikut.

a. Latihan simulasi atau simulation exercise. Merupakan suatu metode pembelajaran, di mana memberikan penyajian tentang situasi nyata yang dapat dikontrol. Siswa berhak untuk melakukan manipulasi terhadap situasi untuk meningkatkan pemahaman siswa terhadap situasi tersebut secara lebih baik. Simulasi jenis ini, dapat meliputi: simulasi dengan menggunakan audio visual dan live simulated patient.

b. Simulation game atau permainan simulasi.

c. Role playing atau bermain peran. Merupakan salah satu metode pembelajaran dengan menggunakan drama. Siswa secara spontan memperagakan suatu peran dalam berinteraksi yang berhubungan dengan masalah dan hubungan antarmanusia.Metode simulasi ini tidak dapat dilakukan secara langsung pada klien. Melainkan dilakukan dengan cara mempraktikkan seolah-olah nyata. Hal tersebut dimaksudkan agar tidak terjadi kesalahan yang lebih fatal. Teknik bermain peran, terdapat tiga jenis, yaitu kasus aktif, model, dan klien.

Ada tiga jenis metode pembelajaran dengan teknik simulasi yaitu latihan simulasi, simulasi permainan, dan bermain peran. Ketiga jenis tersebut, dapat digunakan oleh guru dengan memilih jenis yang sesuai dengan kondisi yang dihadapi. Menerapkan salah satu jenis dari metode simulasi, tidak akan lengkap, tanpa memahami tentang petunjuknya. Petunjuk dalam penggunaan metode simulasi dapat dijelaskan di pembahasan selanjutnya. 
Terdapat beberapa petunjuk yang harus dilakukan oleh guru, ketika menerapkan metode simulasi. Petunjuk-petunjuk tersebut yaitu sebagai berikut.

a. Guru atau pembimbing dalam melakukan suatu simulasi, diharapkan harus dapat meningkatkan dalam mencapai suatu tujuan.

b. Memperhatikan syarat dalam pelaksaan simulasi. Syarat - syarat tersebut berhubungan dengan jumlah siswa, waktu yang diperlukan untuk melakukan simulasi, alat yang digunakan untuk simulasi, dan tempat yang dapat digunakan untuk melakukan simulasi.

c. Guru atau pembimbing harus memahami tentang pelaksanaan dari simulasi.

d. Melakukan uji coba pada kelompok siswa yang telah dikenal oleh guru atau pembimbing.

e. Siswa yang telah memiliki latar belakang berkaitan dengan teori dan keterampilan yang dibutuhkan, diminta untuk ikut berperan serta dalam pelaksanaan simulasi.

f. Siswa harus sudah mengerti tentang tujuan dari peran sertanya pada kegiatan simulasi.

g. Siswa diberikan petunjuk tertulis yang lengkap.

h. Guru atau pembimbing memiliki tanggung jawab untuk menginterupsi simulasi. Hal tersebut terjadi, apabila waktu yang digunakan telah melewati batas dan muncul suatu masalah, selain itu siswa yang terlibat, belum kompeten terhadap kegiatan yang dilakukan.

Terdapat beberapa proses yang harus diperhatikan dalam proses pembimbingan untuk metode simulasi. Proses-proses tersebut dapat dijelaskan sebagai berikut.

a. Guru maupun pembimbing perlu menyampaikan tentang tujuan dari simulasi yang dilakukan.

b. Guru maupun pembimbing perlu memberikan penjelasan tentang jalannya simulasi.

c. Guru maupun pembimbing perlu untuk mengatur siswa dalam memainkan perannya sesuai dengan perannya dalam kegiatan simulasi.

d. Guru atau pembimbing perlu untuk melakukan uji coba. Uji coba ini dapat dilakukan pada siswa yang dikenal oleh pembimbing.

e. Guru atau pembimbing perlu untuk memberikan komentar atau pendapatnya setelah simulasi selesai dilaksanakan. Kondisi ini terjadi, jika ditemukan suatu masalah dan siswa kurang dapat untuk menguasai masalah yang sedang dihadapi.

f. Guru atau pembimbing perlu untuk melakukan diskusi. Diskusi dimaksudkan untuk membahas proses dari kegiatan simulasi.

Penjabaran di atas memberikan gambaran pada guru maupun pembimbing, ketika memberikan suatu bimbingan yang menerapkan metode pembelajaran dengan menggunakan teknik simulasi.

Kelebihan dari metode simulasi, yaitu sebagai berikut.

a. Metode simulasi dapat meningkatkan pengetahuan, sikap, dan keterampilan. Selain itu, memberikan pengalaman secara tidak langsung yang diperlukan oleh siswa untuk menghadapi permasalah yang berhubungan dengan sosial. 
b. Siswa diberikan kesempatan untuk menyalurkan perasaannya yang terpendam. Perasaan yang terpendam tersebut, akan memperoleh kepuasan, kesegaran, dan kesehatan jiwa dengan menerapkan teknik simulasi ini.

c. Metode simulasi dapat membantu siswa dalam mengembangkan bakat dan kemampuan yang dimiliki.

\section{METODE}

Metode penelitian menggunakan penelitian tindakan kelas (PTK) yang dilaksanakan dalam dua siklus setiap siklus terdiri dua kali pertemuan, dengan empat tahap penelitian: perencanaan, pelaksanaan, pengamatan dan refleksi. Subjek penelitian ini adalah siswa-siswi kelas VIII B SMP Negeri 7 Sukoharjo tahun ajaran 2017/2018. Dengan jumlah 31 siswa. Teknik pengumpulan data yang digunakan adalah observasi, wawancara, tes, dan dokumentasi. Analisis data yang digunakan dalam penelitian ini adalah analisis deskriptif kualitatif.

\section{PEMBAHASAN}

Setelah peneliti melaksanakn tindakan penelitian melalui penerapan metode simulasi, secara empiris diperoleh data peningkatan hasil belajar TIK materi menggunakan perangkat lunak pengolah kata word 2007 siswa kelas VIII B SMP Negeri 7 Sukoharjo Kecamatan Sukoharjo, Kabupaten Sukoharjo semester I Tahun Pelajaran 2017/2018 dari kondisi awal, siklus I dan siklus II sebagai berikut.

Tabel 1. Peningkatan Prestasi Belajar Siswa

\begin{tabular}{|l|c|c|c|}
\hline Uraian & Kondisi awal & Siklus I & Siklus II \\
\hline $\begin{array}{c}\text { Tindakan } \\
\text { Pembelajaran }\end{array}$ & $\begin{array}{c}\text { Belum menerapkan } \\
\text { metode simulasi }\end{array}$ & $\begin{array}{c}\text { Sudah menerapkan } \\
\text { metode simulasi }\end{array}$ & $\begin{array}{c}\text { Sudah menerapkan } \\
\text { metode simulasi }\end{array}$ \\
\hline Nilai terendah & 60 & 60 & 70 \\
Nilai tertinggi & 80 & 90 & 90 \\
Nilai rata-rata & 70 & 75 & 85 \\
KKM & 75 & 75 & 75 \\
Ketuntasan & 18 siswa $(58,06 \%)$ & 21 siswa $(67,74 \%)$ & 27 siswa $(87,09 \%)$ \\
\hline
\end{tabular}

Melalui penerapan metode simulasi dapat meningkatkan hasil belajar TIK materi menggunakan perangkat lunak pengolah kata word 2007. Pada kondisi awal peneliti belum menerapkan metode simulasi. Nilai rata-rata siswa kelas VIII B adalah 70, masih di bawah nilai KKM yang ditetapkan yaitu 75. Nilai tertinggi siswa 80, nilai terendah 60 dan jumlah siswa kelas VIII B yang mencapai nilai KKM hanya 18 siswa $(58,06 \%)$ dari total 31 siswa kelas VIII B SMP Negeri 7 Sukoharjo.

Pada siklus I guru peneliti sudah menerapkan metode simulasi dalam pembelajaran TIK materi menggunakan perangkat lunak pengolah kata word 2007. Nilai rata-rata hasil belajar TIK siswa kelas VIII B SMP Negeri 7 Sukoharjo adalah 75, nilai tertinggi 90 dan nilai terendah adalah 60. Sedangkan jumlah siswa yang mencapai nilai KKM sebanyak 21 siswa $(67,74 \%)$ dari total 31 siswa kelas VIII B SMP Negeri 7 Sukoharjo. 
Pada siklus II, nilai rata-rata hasil belajar TIK siswa kelas VIII B SMP Negeri 7 Sukoharjo adalah 85, nilai tertinggi 90 dan nilai terendah 70. Jumlah siswa yang mencapai nilai KKM sebanyak 27 siswa $(87,09 \%)$ dari total 31 siswa kelas VIII B SMP Negeri 7 Sukoharjo.

Jadi, melalui penerapan metode simualsi dapat meningkatkan hasil belajar TIK dari kondisi awal nilai rata-rata 70 dengan ketuntasan 58,06\% ke kondisi akhir pada siklus II nilai rata-rata 85 dengan ketuntasan $87,09 \%$ pada siswa kelas VIII B SMP Negeri 7 Sukoharjo semester I Tahun Pelajaran 2017/2018.

Hasil tindakan secara empirik yaitu: melalui penerapan metode simulasi dapat meningkatkan hasil belajar TIK materi menggunakan perangkat lunak pengolah kata word 2007 dari kondisi awal nilai rata-rata 70 dengan ketuntasan 58,06\% ke kondisi akhir pada siklus II nilai rata-rata 85 dengan ketuntasan 87,09\% pada siswa kelas VIII B SMP Negeri 7 Sukoharjo semester I Tahun Pelajaran 2017/2018.

\section{SIMPULAN}

Hipotesis menyatakan diduga melalui penerapan metode simulasi dapat meningkatkan hasil belajar TIK materi menggunakan perangkat lunak pengolah kata word 2007 pada siswa kelas VIII B SMP Negeri 7 Sukoharjo semester I Tahun Pelajaran 2017/2018. Dari data empirik menyatakan melalui penerapan metode simulasi dapat meningkatkan hasil belajar TIK materi menggunakan perangkat lunak pengolah kata word 2007 dari kondisi awal nilai rata-rata 70 dengan ketuntasan $58,06 \%$ ke kondisi akhir pada siklus II nilai rata-rata 85 dengan ketuntasan 87,09\% pada siswa kelas VIII B SMP Negeri 7 Sukoharjo semester I Tahun Pelajaran 2017/2018. Sehingga dapat disimpulkan bahwa melalui penerapan metode simulasi dapat meningkatkan hasil belajar TIK materi menggunakan perangkat lunak pengolah kata word 2007 pada siswa kelas VIII B SMP Negeri 7 Sukoharjo semester I Tahun Pelajaran 2017/2018.

\section{DAFTAR PUSTAKA}

Ahmadi, Abu. (1998). Psikologo Pendidikan. Jakarta : Rineka Cipta

Anitah, Sri, W, dkk. Strategi Pembelajaran di SD. Jakarta: Universitas Terbuka, 2007

Dimyati dan Mudjiono. 2006. Belajar dan Pembelajaran. Jakarta: Rineka Cipta

Kementerian Negara Riset dan Teknologi Republik Indonesia. (2006). Buku Putih Penelitian, Pengembangan dan Penerapan Ilmu Pengetahuan dan Teknologi Bidang Teknologi Informasi dan Komunikasi Tahun 2005-2025 Republik Indonesia.

M. Sobry Sutikno. 2010. Strategi Belajar Mengajar Melalui Penanaman Konsep Umum \& Konsep Islami. Refika Aditama: Bandung.

Nasution. 1995. Metode Research. Jakarta : PT. Bumi Aksara

Ngalim Purwanto. 1986. Psikologi Pendidikan. Bandung: PT Remaja Rosdakarya. 
Endar Setyawan / Edunomika Vol. 02 No. 01 (Pebruari 2018)

Ngalim Purwanto. 2008. Metodologi Penelitian Kuantitatif. Yogyakarta: Pustaka Pelajar Pusat Bahasa Depdiknas. (2005). Pengertian metode Simulasi. Pusat Bahasa Depdiknas Slameto. 2000. Belajar dan Faktor-faktor yang mempengaruhinya. Rineka Cipta,Jakarta Suprijono, Agus. 2011. Model Pembelajaran Kooperatif. Jakarta: Bumi Aksara

Syaefudin, Udin. (2005). Perencanaan Pendidikan Pendekatan Komprehensif. Bandung: PT Remaja Rosdakarya.

Tho'in, M. (2017). Pembiayaan Pendidikan Melalui Sektor Zakat. Al-Amwal: Jurnal Ekonomi dan Perbankan Syari'ah, 9(2).

Winkel, W. S. (2004). Psikologi Pendidikan dan Evaluasi Belajar. Jakarta: PT. Gramedia Pustaka Utama. 